УДК 821.161.2-1.09 Римарук

Анісімова Ніна,

доктор філологічних наук, професор кафедри української та зарубіжної літератури і порівняльного літературознавства

Бердянський державний педагогічний університет

\title{
ХУДОЖНЯ ТРАНСФОРМАЦІЯ ГЕРМЕНЕВТИЧНИХ КОНЦЕПЦІЙ МАРТІНА ГАЙДЕГІЕРА У ЛІРИЦІ ІГОРЯ РИМАРУКА
}

\begin{abstract}
У статті проаналізовано мотив творчості та образ Поета у ліриці представника поетичного покоління 1980-х років Ігоря Римарука. Теоретичною основою дослідження обрано герменевтичні концепиії Мартіна Гайдељ'ера, висловлені ним у праиях «Навіщо поети?», «Гельдерлін $i$ сутність поезї̈». Простежено драматичні колізії $i$ внутрішні конфлікти мотиву творчості у поетичних збірках I. Римарука, зумовлені міфологемою «проклятого поета», що мае давні традичії в украӥнсъкій літературі. Аналізуеться художня самобутність поетичних текстів. Визначаеться естетична оригінальність філософсъких мотивів на матеріалі поетичних збірок I. Римарука «Сльоза Богородиці», «Божественний вітер».
\end{abstract}

Ключові слова: лірика, стилет, стилос, герменевтичні концепцї̈, ліричний суб'єкт, мотив, метафоричний образ.

\begin{abstract}
Anisimova N. Artistic transformation of Martin Heidegger's hermeneutic concepts in the lyrics of Igor Rymaruk.

The article analyses the motive of creativity and the image of the Poet in Igor Rimaruk's lyrics, the representative of the poetic generation of the 1980s. The theoretical basis for the study was Martin Heidegger's hermeneutical concepts expressed in the works «Why do poets?», «Helderlin and the essence of the poetry». Dramatic colisees and internal conflicts of the motive of creativity have been Illuminated in I. Rimaruk's poetical collections, caused by the myth of the «accursed poet», which has long traditions in the Ukrainian literature. The ontological regularities have been thoroughly examined in the functioning of the philosophic concept of the individual alienation from the world and his influence on the modelling of the author's world picture. The main attention has been paid to the opening of existential lyrics discourse, connected with the loneliness existential, alienation of the individual from the world and others. The hermeneutic dialogue of I. Rymaruk's lyrics with the philosophical ideas of M. Heidegger is based on the discussion about the dominant role of the ideological or aesthetic function of creativity The lyrics of I. Rymaruk in the aesthetic plane polemicises around the eternal dilemma: the real Poet must be a Prophet or uphold the ideas of «pure lyrics» - stay
\end{abstract}


98 Літератури світу: поетика, ментальність і духовність. 2020. Bип.14

in the world of beauty and art The opposition «damned poet» / «real poet» has been analysed through the prism of the Heidegger's concept of the language essence of literary works. The artistic peculiarity of poetic texts is analysed. The aesthetic originality of philosophical motives on the material of I. Rymaruk's poetic collections «The Tear of the Virgin», «Divine Wind» has been determined. A comparative analysis of Igor Rymaruk's poetry has been made with the typologically similar lyrics of the Prague School representatives - Oleg Olzhich and Eugene Malanyuk. The artistic peculiarity of the poetry has been defined. The line of expressive means which are typical for the poet has been characterised: psychologism, meditativity, contrast, metaphorism.

Key words: lyrics, stylet, stylos, hermeneutical concepts, lyrical subject, motive, metaphoric image.

В українській поезії кінця XX - початку XXI століття Ігор Римарук упевнено посів місце ключової постаті модернізму, визнаного лідера генерації 80-х років XX ст. Про його творчість у сучасній літературознавчій думці не бракує статей та рецензій. Серед дослідників утвердився одностайний погляд щодо елітарного і герметичного змісту Римарукової лірики, а самого автора називають поетом «книжним», «філологічним», продовжувачем неокласичних традицій.

Постановка проблеми. Наскрізним мотивом лірики I. Римарука є філософське осмислення сенсу творчості і визначення місця Поета у суспільному поступі. Художні аспекти традиційного для української поезії мотиву лише почасти були предметом дослідницьких студій. Одна з них належить Наталії Лебединцевій, яка розглянула роль Слова у сакральному дискурсі лірики М. Зерова і поетавісімдесятника [5]. Слушними є міркування дослідниці щодо опозиції слова як носія сакрального сенсу та спрофанованого спекулятивного слова, знівельованого сучасниками [5, с. 51]. В. Моренець наголосив, що у другій половині XX століття в українській поезії набув потужного розвою стильовий напрям - естетизм [7], прибічники якого «виносили на перший план естетичні начала творчості й обстоювали літературу в її іманентній сутності, художній автономності, не підлеглій позамистецьким сферам, але рівновеликій їм» [6, с. 250]. Представниками естетизму, на думку В. Моренця, є М. Вінграновський та I. Римарук, яких поєднує тяжіння до засад «чистого мистецтва», до естетичної вишуканості та артистизму, що означилися ще на початку XX століття у творчості поетів «Молодої Музи» [7]. Суголосний погляд обстоює й Ірина Комаренець, яка, простеживши стильову еволюцію I. Римарука, вказала на глибоке осмислення поетом «проблематики слова, критеріїв його істинності, пошук зв'язку зі словом вічним, сакральним» [4]. 
Чимало глибоких думок щодо власної творчої лабораторії висловив сам Поет у численних інтерв'ю [3]. Попри певну кількість критичних публікацій, асоціативно-метафоричний і герметичний зміст Римарукової лірики, присвяченої філософському мотиву творчості та образу Поета, потребує герменевтичних студій. Методологічну основу запропонованої студії становлять герменевтичні концепції М. Гайдеггера, висловлених у працях «Навіщо поети» та «Гельдерлін і сутність поезіі». Висвітлення естетично-філософських аспектів лірики I. Римарука та виявлення шляхів їх художньої реалізації слугуватиме поглибленому уявленню про творчі пошуки представників модернізму у середовищі генерації вісімдесятників.

Мета запропонованої статті - проаналізувати діалог лірики Ігоря Римарука з герменевтичними концепціями Мартіна Гайдег'гера, визначити філософсько-естетичні аспекти художньо трансформованих мотивів та образів у творчості поета-вісімдесятника.

Виклад основного матеріалу. У кінці XX століття - час складного вивільнення української літератури з-під влади ідеологічних догм - знову набула актуальності давня полеміка щодо справжнього призначення Поета - служити стилету чи стилосу? 3 цього погляду засадничим є твердження М. Гайдегґера, який вказав на тісний зв'язок творчості Поета з культурно-історичними реаліями: $<<\ldots>$ сутність поезії закорінена у своєму часі. Однак вона не пристосовується до свого часу, як до чогось уже існуючого. ґельдерлін, коли знову у-становлює сутність поезії, тим самим окреслює новий час. Це є час Богів, які втекли, і Бога, який надходить» [2, с. 260]. У поетичних збірках «Висока вода», «Діва Обида», «Сльоза Богородиці», «Бермудський трикутник», «Божественний вітер» І. Римарук в естетичній площині полемізує навколо одвічної дилеми: справжній Поет має надавати перевагу стилету (тобто перебирати на себе функції пророка - за допомогою Слова вдосконалювати навколишній гріховний світ, наближати його до сакральних засад Святого Письма) чи стилосу (відстоювати засади «чистої поезії» - перебувати у світі понадземної краси і мистецтва, сповідувати гедонізм). Погоджуючись в основному 3 поглядом В. Моренця щодо тяжіння I. Римарука до естетизму, завважу, що для ліричного суб'єкта його поезії проблема вибору між елітарністю і громадянськими почуттями є не однозначною і надзвичайно складною, що засвідчує вірш-полеміка з Є. Маланюком: «Стилет i стилос повелосъ іздавна. / Ба й нині очі в Музи крем'яні. / Та що лункіш хода ї̈ державна, / то з кожним днем милішае мені / післяобідній відпочинок фавна... / O, ти б перевернувся у труні, / хоч раз почувши 
тирлище ревуче / страждальиів за вітчизну, Маланюче!» [8, с. 294]. Процитовані рядки просякнуті гострою іронією і сприймаються як прихована дискусія з віршами Є.Маланюка («Стилет чи стилос») і О. Ольжича («В робітні»). «Пражани» художньо втілювали «міф "проклятого поета"» - неоромантика-борця, що йде на барикади задля досягнення суспільно значущої ідеї, жбурляючи себе у вир боротьби та принижуючись до рівня натовпу. Є. Маланюк відверто надавав перевагу стилету, суголосно й О. Ольжич ганьбив поета, що замкнув себе в робітні, відірвався від суспільних проблем часу. Естетична концепція «пражан» простежується й у ліриці I. Римарука, однак набуває оригінального перетлумачення. Поет стає заручником свого таланту, а його свідомість потрапляе в зачароване коло: стати на шлях боротьби - зрадити свій дар, а отже, померти і як митець, і як людина, зачинитися в робітні - знов утратити себе морально: «Скілъки запилених личь / та прихистила робітня! / Скілъки затоптано криз / на виноградниках слави!...». Драматичний вибір між стилетом і стилосом автор відтворює за допомогою метафоричного образу «голосів керамічних»: «Пізня година. Довкіл - / клятви й розкаяння звичні. / Знову лягають, як пил, / на голоси керамічні / ложне смирення столиць / i провінційність амбітна» («Голоси») [8, с. 67]. Згідно з гайдеггерівською концепцією про сутність поезії ліричний суб'єкт не пристосовується до ідеологічного диктату часу, а прагне якісно оновити його, наповнити вищим, сакральним змістом, пізнати найсокровенніші таємниці «часу Богів» (М. Гайдегґер).

Уникаючи будь-якого декларативного підходу і прагнучи водночас протидіяти фатуму «проклятих поетів», I. Римарук наскрізну міфологему української літератури подає у філософському аспекті. Трагізм українського Митця у тому, що впродовж тривалого періоду він мусить творити у час суспільних потрясінь, які М. Гайдегґер називає «убогим часом», «епохою відходу Бога», «браком Бога», «часом світу ночі» [1, с. 230]. І. Римарук доходить висновку: специфіка українського митця в тому, що він мусить існувати всупереч реальності, в абсолютно забороненому для себе світі, у-становлювати (М. Гайдеггер) нову якість поезії. Жертовність митця зумовлена як природою його творчого обдарування, так і прив'язаністю до безперервного ланцюгу «проклятих поетів» України. Ця світоглядно-естетична дуальність передана у метафоричній площині через протистояння «нічних голосів», що символізують громадянську визначеність Поета, його сумління, i «катренами», які вказують на ірраціональну природу творчого натхнення, непідвладність його будь-яким ідеологічним канонам i 
нав'язливим стереотипам. Усвідомлення суспільного призначення Поезії автор виражає через низку герметичних метафор: «Ці нічні голоси - / иі закинуті в моторош митарі - / комірчину твою не забудуть, / проси не проси: / ти накликав їх сам, / ̈̈х шукав у вселенсъкім гармидері, / i на вбогу свічу / прилетіли нічні голоси». Простежується парадоксальність процесу творчості: «справжній» Поет перетворюється на «вар'ята», який, протидіючи ідеологічним утискам (у поезії їх уособлюють «убивць голоси»), наповнює свої «катрени» «пророчими словами» та прихованим змістом: «Потаємні вони - / а тобі закортіло катренами / розікласти по аркушах $\ddot{\imath x}$ - / о свята простота! / Але вбивць голоси / прикидались тоді убієнними, / а пророчі слова / заповзали вар'ятам в уста» («Нічні голоси») [8, с. 218]. Внутрішня драматична боротьба у душі Поета завершується перемогою таланту (образ «празникової зорі»), пріоритетом естетичного над ідеологічним (останній втілюють образи «нічних голосів - покликачів»).

1980-90-ті роки для українського митця - це «убогий час», тому Поет у ліриці І. Римарука, як і актор, нагадує камюсівську абсурдну людину: він відчуває марність своєї творчості, яка вже не приносить насолоди, проте не може не писати, не братися за перо: «Tu - сцена $i$ актор в порожнъому театрі. / Ти побутову мить зіграеш - $i$ за мить / чи туга, чи нудъга, палаючи, мов натрій, / крізъ опівнічниц зал у темряві летить» («До Слова») [8, с. 122]. Для ліричного суб'єкта I. Римарука, за М. Гайдег'гером, «Бути поетом в убогий час означає: співаючи, йти слідом відлинулих богів. Тому й поет в час світової ночі промовляє Святе» [1, с. 230]. «Убогий час» для вісімдесятника - це так звана «перехідна» доба останньої чверті XX століття, коли соцреалізм був остаточно дискредитований, а література загалом переживала складні процеси постколоніального травматизму. Естетичне оздоровлення поезії в I. Римарука трансформується за допомогою метафор «реставрування» Слова й «відчитування» пережитого досвіду: «I реставруеш літери зникомі, / й життя свое відчитуєш назад: / немов у велетенсъкім паліндромі, / в абсурді віднаходиш певний лад». Порівняння поезії з «велетенським паліндромом» $\mathrm{i}$ «зникомими літерами» увиразнює драматичну сутність конфлікту між стилетом і стилосом. Сам процес творчості приносить жадане заспокоєння, хоч і не позбавляє мук, стаючи абсурдом: «Т віщий сон, то сніговій, то розчерк, / то строфи, для світанку затісні.. / Про музику й поезію торочиш, / розвішуеш картини на стіні». В «убогий час» панування кон'юктурних підходів до 
творчості для Поета є не прийнятними «марнославство»і «марева» облудних обіцянок можновладців: «O племена мелодій, барв $i$ літер, о марнославні маревні полки! / У ваші вежі божественний вітер / скеровуе віки, мов літаки» [8, с. 293]. Використовуючи прийом іронії, поет зображує трагедію митця, який в «епоху відходу Бога» потрапив у пастку власних ідей, гордовито замкнувши себе у «вежі» творчого усамітнення, прагнучи зберегти сакральну сутність $y$-незалежненого (М. Гайдеггер) від будь-яких упливів Слова.

Згідно з гайдег'ерівською концепцією постає питання: що значить «іти слідом відлинулих богів»? що означає «промовляти святе у час «світової ночі»? Відповіді на ці філософські питання дає поезія «Від’їзд» I. Римарука, у якій порушено актуальну проблему переслідування поетів деспотичними режимами: «Час вирушати, о лищарство вперте, / пристрасті наші були замалі, / наша сторінка дописана verte: / «Mи не поети. / Поети - в землі». Процитована поезія порушує проблему творчості як обраності долею: справжні Поети не підвладні меркантильному духові часу, у їхньому колі немає місця для конформістів, вони вільні і незалежні: «Ні вечорнииі, ані власяниці / в коло обранців / не впишуть приблуд». Живі поети несуть на собі тяжкий хрест громадянської відповідальності перед поколінням «розстріляного відродження», представники якого постають моральними авторитетами для вісімдесятників. I. Римарук утверджує зв'язок творчих генерацій: «A з-під землі повиходять поети - / знову дорогу спитають в зірок» [8, с. 220]. Не випадково епіграфом до поезії автор узяв слова М. Зерова: «Я від'їжджав $i$ оком астролога допитувався в зір - яка дорога мене провадить у майбутні днi» [8, с. 220]. Для поетів - і неокласика, і вісімдесятника майбутнє є у тих митців, які сповідують засади вільної творчості, для яких свобода $є$ альфою й омегою існування у світі. «Коло обранців» для І. Римарука - це поети-нонконформісти, які прокинулися після «чергового примусового летаргічного сну українського слова (19671987 рр.)», яким не байдужі питання національної самосвідомості українців [3].

У ліриці І. Римарука опозиція «проклятий поет» / «справжній поета» прочитується крізь призму гайдег'ерівської концепції про сутність мови художніх творів. Філософ пропонував розмежовувати буденну, побутову мову (das Gerede), що є поверховою, та мову істинну, де-автоматизовану (die Sage), яка безпосередньо співвідноситься 3 онтологічною істиною буття [1, с. 227]. Зрозуміло, що з них саме друга є мовою Поезії, адже «Поезія вирує у стихії ви-словлювання та 
мислення» [1, с. 228]. Марія Зубрицька завважила: «Те, що Гайдеггер розуміє під «висловлюванням», істинною мовою (die Sage) - це артикуляція повноти значень Dasein (тут-буття); висловлювання артикулює себе у таких формах розкривання, як дієвість, мовчання, мистецькі твори $\langle\ldots>$. Висловлювання включає вслуховування, мовчання і грунтується на розумінні» [1, с. 227].

Підгрунтям «справжності» для ліричного суб'єкта I. Римарука $є$ свобода творчості, за яку в українському культурному просторі тривала багатовікова виснажлива боротьба, що постає в метафоричному образі снігопаду: «O прийди - / навпростещь, невпопад, / одиуравшись $i$ племені й роду... / о, допоки трива снігопад, / подаруй цьому слову свободу!» («Дди, поки падає сніг...») [8, с. 88]. Осмислюючи проблему «митець і суспільство», поетизуючи світ мистецтва, I. Римарук змальовує збірний образ богоподібного творця - деміурга, що виступає в різних іпостасях («братове», «лицарство вперте», «брате», «нічний друг», «чоловіче»), він же - жертва, мученик із печаткою прокляття на чолі, індивідуальність серед натовпу, який не здатний зрозуміти митця. Ліричний суб'єкт Римарукової лірики своєю пасіонарною жертовністю нагадує Месію, подвижницькі вчинки якого не розуміє несвідомий гріховний натовп, закидаючи його камінням: «Осъ тобі за твій ковток свободи, / за вчорашній кусень житняка, / за щілинку вибору, за віру / в незітліле древне знамено, / за печальну пісню тонкошкіру / камінь у засвічене вікно!» [8, с. 157]. У поезї «Камінний лист» прочитується важлива ідея: попри всі загрози і навіть небезпеку, «справжній» поет завжди наділений чутливою душею, унікальною здатністю до безкомпромісного, чесного слова як до найвищої цінності, загостреним відчуттям свободи.

У поезії І. Римарука гайдеггерівська концепція істинної мови в естетичній площині виражається через опозицію «справжне фальшиве». Поет постійно акцентує протистояння контрастних образів: «вільне», сакральне поетичне слово - заангажоване; світло темрява; митець - конформіст тощо. Образ вільного митця постає у поезї̈ «Автопортрет» скульптора Івана Мердака». Автор порушує проблему сенсу творчості, мистецького покликання: у справжнього майстра на скульптурі «дерев'яна рука ожива». I. Римарук пише про відповідальність кожного поета за свою поезію: «Хай не виполе / дикоростучі / безпритульні слова! / Хоч вони й неприглядні / в підніжжсях / вертикальних осяянь, - / а все ж / не клади, мов коріння, під нію їx: / вдосконалиш - уб'єu». Джерелом творчого натхнення має стати поезія, вільна від ідеологічних упливів, як- 
от лірика Б.-І.Антонича: «Тілъки що захистити їх може, / що затулить чей віщий бур'ян? / Може, лемківсъка туга? / чи, може, подоляиький туман?» [8, с. 66]. Отже, і поет Б.-І. Антонич, і скульптор Іван Мердак - це носії істинної мови (die Sage), сповідувачі справжнього мистецтва, які у час панування «світової ночі» у «тут-бутті» зберегли внутрішню самодостатність та незалежність. Внутрішній конфлікт Римарукової поезії будується на протистоянні двох світів - світ творчості (реалізується через образи «вертикальні осяяння», «коріння») - світ приземлено-матеріальний (образи «віщий бур'ян», «дикоростучі слова»). Розуміння природи творчості передане метафорою - справжнє мистецтво народжується лише від світла (Істина, Краса, Добро, Свобода), від єдиного джерела - вогню, який повинен стати єством митця і спалити його. У низці віршів образ Слова як символу Світла набуває різних метафоричних відтінків: означає пізнання навколишнього світу й осягнення місця людини у ньому («слова ранковий n'ястук», «світло покласти в зіницю» $[9$, с.9]); виражає ідею осмислення життєвих протиріч («Навколо світ, болючий знову. / А як бажалося колись / із нъого вихопити слово, / немов дитину з-під коліс...» [8, с. 25]); втілює філософію існування індивіда у світі («Ще слово в хату заліта, / ще молоде й лунке неначе, / та вже не плаче, вже не плаче / висока свічка золота» («Гравюра зі свічею») [8, с. 41]); асоціюється зі збереженням історичної пам'яті нації («I тільки Слово стереже могили - / як мертвий скіф на мертвому конi» $[8$, c. 204]); вказує на освячену вищими силами сакральну природу процесу творчості («У самовитім чи в несамовитім - / у кожнім слові глядь $i$ непроглядъ.. / Якого ж ока треба самовидиям, / щоб азбуку століття розпізнать?» («Репліка в дискусії) [8, с. 51].

М. Гайдеггер розрізняв поезію «сущого» та поезію «буття». «Суще»це весь навколишній світ, із яким індивід контактує повсякденно. Натомість «буття» - те, що поза межами світу, вихід на рівень Вічного. «Вихід» у Буття, за М. Гайдегґером, є завжди ірраціональним: на відміну від звичайних людей, які, існуючи у сущому», не здатні вийти за його межі, Поет, наділений інтуӥцією, творчою фантазією i прозрінням, може привідкрити завісу за «лаштунки Буття». У момент такого натхнення Поет із звичайного ремісника перетворюється на Творця високої Поезіі. У низці віршів І. Римарука («Голоси», «Нічні голоси», «Якщо помиливсь») утверджується концепт свободи творчості, вірності своєму покликанню «справжніх» поетів у mym-бутmi. Їм автор протиставляє конформістів - це так звані «міщани елітарні», які сповідують «поезію кав'ярні та ліхтарні». Поет пише про них з іронією, 
що подекуди переростає в сарказм: «Зламавши власну душу, як гілляку, / у душу їм, / чутливу, як струна, / я вихлюпнув би наймічнішу лайку, / мов склянку найдешевшого вина...». Не випадково вірш називається «Автосарказм»: поет іронізуе над самим процесом творчості, коли кожен митець переживає «добірні грона муки» і не в змозі звільнитися від їх упливу: «але трима поезія за руки» [8, с. 103]. Для ліричного суб'єкта I. Римарука творча свобода є необхідною умовою існування, адже будь-які утиски і зовнішні втручання є згубними для справжнього таланту («Нікогісінько не візьму. ..», «Ми надійшли - чи скопом, чи вертепом», «У дні безхлібні та безводні», «Вже не стачить старих підошов», «Тут не знайдете мене ви»).

За М. Гайдег'ером, «сутність поезії втягуе в орбіту законів і божественних знаків і голосу народу, які то сходяться, то розходяться. Сам Поет стоїть посередині - між Богом і народом. Його викинуто у це Між, між Богами і людьми» [2, с. 260]. Вплив «людського» проявляється у тому, що Поет у ліриці І. Римарука не позбавлений сумнівів, вагань і навіть розпачу: ці не властиві для ранньої лірики мотиви на повен голос починають звучати у віршах «Бермудського трикутника»: у поєдинку зі світом ліричний суб'єкт книжки виступає не переможцем, а переможеним: «ну поразка в цвому світі ти програв / в тому світі між смаколиків приправ / фоліантів манускриптів прибамбасів / ти кохався віршував $i$ вар'ював / воював із вітряками вчивсь у трав / але світ тебе матолка віддубасив / остогидли золоті ворота й вал / ти поїдеш на опівнічний вокзал / рушить потяг $і$ шукайте в сіні голку / нумерачія вагонів з голови /нумерація агоній з булави / отже слухай оголошення маточку» («Napomnienie od... ») [8, c. 360]. Однак сумнів і вагання для Поета не є злом, оскільки, за М. Гайдег'ером, «буття взагалі є цілковитим ваганням і ризиком. Воно зважує нас, людей $<\ldots>$. Буття сущого є ризик» [1, с. 233]. Через сумнів і вагання ліричний суб'єкт Римарукової лірики здобуває право наблизитися до пізнання сутності mym-бутmя і, зрештою, осягнути гармонійну цілісність своєї Самості.

М. Гайдегґер, аналізуючи поезію Рільке, на означення творчої свободи, яка $є$ необхідною умовою поетичного натхнення, вживає поняття «Відкрите». На думку герменевта, «Відкритим» у мові Рільке називається те, що не замикає. Воно не замикає, тому що не обмежує. Воно не обмежує, тому що в собі самому позбавлене будь-яких меж. Відкрите є великим цілим всього того, що необмежене» [1, с. 233]. У поезії І. Римарука концепція «Відкритого» пов'язана з ірраціональною природою творчості: усвідомлюючи суспільне призначення поезї 
106Літератури світу: поетика, ментальність і духовністъ. 2020. Bип. 14

(стилет), поет воднораз наголошував на містичності як засадничій рисі Божого дару, його освяченості вищими силами (стилос). Творче натхнення може персоніфікуватися: до митця вночі приходить «нічний друг», який змушує поета страждати і творити: «A nотім, / од заслиненого крику / відмивши віршем пам'ять, як підвал, / повіки стулить... / I блаженна тьма / сповзе на тебе з них, немов би з лісу... / Вставай. Іди. Рядки повторюй. Злися: / «Щоб він пропав»! Таких ... таких нема» («Таких нема...») [8, с. 120]. I. Римарук уважає, що справжнє натхнення має ірраціональну природу, а тому допускає втручання вищих сил у процес творчості: «Коли під ранок ти відчуєш знову, / що речення тісні, мов коміриі, / $i$ розірвеш строфу восвмирядкову, - / вважай: че крутять блюдечко мериі / $i$ дух твій викликають на розмову. / Мовчи. Мовчи. Того, що ждуть спірити, / не велено живому говорити» [8, с. 291]. Найвищою кульмінацією поетичного натхнення є творче шаленство, що відчиняє двері у світ «Відкритого»: «Коли світанок давні вірші / сховае, мов листи за мисник, / а віщі вірші - ще давніші - / у голові мойи замісить, / тоді повільно і свавільно / шаленство зійде, наче тісто... / I де на світі божевільня, / в якій мені не буде тісно?!» [8, с. 214]. Для Поета творчість - це основна подія буття, вільний політ душі, творчої уяви, це «автентичний творчий рух» (М. Гайдеґґер).

Концепція «Відкритого» не має на увазі небо, повітря і простір. Поетові йдеться про ту «несказанно відкриту свободу, еквіваленти якої є, мабуть, хіба тільки в першу мить кохання, коли людина в іншому, коханому бачить свої власні овиди, чи, може, у щонайвище хвилинній піднесеності до Бога» [1, с. 235]. Сутність «Відкритого» у поезії І. Римарука конкретизують образи сакрального наповнення «Божа іскра», «щебетання солов'я», свист вітрогану: «I Божу іскорку, й ім'я - / бо все своє - / захланним хрипом холуя / він продає. / Це там, удома.. Тут же, де / суціль бедлам. / на мене каменем впаде / ім'я - Іслам. / Заради цвого, може, влип / я в той Кемер: / почути не сопливий схлип, / а скрип галер. / Не щебетання солов'я, / $i$ вітроган. / Отак висвистуе ім'я - / мов ятаган. / Мені насправді той Іслам / ні світ, ні кум. / Хіба що продае ослам / рахат-лукум» [9, с. 140]. Поезія просякнута внутрішнім драматичним конфліктом: звичайна людина не впущена у «Відкрите», позаяк вона протиставлена світові. У посмертній книжці I. Римарука «Божественний вітер» починає звучати не притаманний для його попередніх збірок мотив продажності таланту, вірш наповнюється саркастичними інтонаціями у зображенні поетаремісника, поета-лжепророка, які посилюють образи «захланного хрипу холуя», «бедламу», «сопливого схлипу». 
У поезії І. Римарука поширений образ братів по перу (автор неодноразово вживає форму звертання - «братове»). У «Диптиху» поет протиставляє «газетне ремесло» «проклятих поетів» справжній творчості, покликанню: «Братове, хто стояв при слові у сторожі, / коли спішили ми - та не до творчих мук - / $i$, наче ицгарки, під ранок, іскри божі / гасили об каблук? / В пустелі глас лунав / а все ж когось діймало: / захиріло б без нас газетне ремесло... / Щасливець був поет, який писав: «Нас мало», - / нас, може, й не було?» [8, с. 63]. Поезія «Ми стали неписьменними...» може сприйматися як кульмінація у розвитку мотиву приреченості «проклятих поетів» служити ідеї: «Стократ прокляте наше ремесло / свої видіння волочить на люди. / Ми ще не прочитали, що було. / A те, що е, - нехай $i$ завтра буде» [8, с. 48]. Процитовані поезї засвідчують широке інтертекстуальне поле Римарукової лірики, що потребує окремих студій. Зокрема, у вірші «Братове, хто стояв при слові на сторожі» вгадується Шевченкове «я на сторожі коло них поставлю слово»: обидва поети усвідомлювали роль стилету у формуванні національної свідомості.

Узагальнений образ поетів-ремісників, поетів-конформістів постає у вірші «Перед «Автопортретом зі свічкою» Тараса Шевченка», що має форму ліричного послання до тих співвітчизників-«народолюбців», хто всує «клянеться Шевченком». У вірші вчувається прихована полеміка автора 3 «офіційними» шістдесятниками, які пішли на співпрацю 3 тоталітарним режимом у «застійну» добу, зрадили своєму покликанню. Поет знаходить експресивно забарвлені метафори, щоб викрити тих, «хто щедро платив на відомий мотив / дань усім одноденкам / а на кручу зіниці камінні котив...». У вірші прочитується, за В. Моренцем, «глумливий примруг до остогидлого літературного, а ширше - життєвого стилю, простота і ясність якого в художньому плані були дешевим ремісництвом, а в світоглядному - безсовісною кон'юктурою і духовним фальшем» [7, с. 397]. Поезія насичена гострою іронією та сарказмом у зображенні образу новітнього «лжепатріота»: «та не клятви кликуш i не платний кунтуш / у Шевченківсъкій спадку - / а кошуля катуш а незгашених душ /піднебесна загадка / $i$ хоча шукача водномить від ключа / ви плечем одітрете / але світить йом молоденька свіча / та що з Автопортрета». Поети-конформісти «насунули смушком собі на чоло / правдолюбіє кволе», вони «n'ястуком каяття обчухрали життя». Образ свічки у вірші - це символ живого світла (істинної мови), шлях Поета у сферу «Відкритого», що знайшов своє вираження у творчих долях поетів-дисидентів, які не скорилися і 
вистояли у похмуру добу «застою» («неспроста шукачів що ішли при свічі / ви лякали Шевченком») [8, с. 236].

М. Гайдегґер писав про Гельдерліна як про «Предтечу поетів у нужденний час». Подібне можна твердити про I. Римарука: на тлі сучасних постмодерністських пошуків вічні мотиви його лірики вкотре спонукають до розмислів над буттям нації та місце у ньому Поета. Вісімдесятник став предтечею того покоління поетів, яке ще має з'явитися в українській модерній ліриці і сказати нове слово. «Так само, як не можна перегнати предтечу, так само він мало минущий; бо його поезія залишається такою, що від-булася (Ge-wesenes). Те, що є у природі, збирається знову у долю. I те, що таким чином ніколи не потрапить потік занепаду, наперед долає всяку минущість» [1, с. 249].

Висновки та перспективи дослідження. Таким чином, поету-вісімдесятнику I. Римаруку притаманна онтологізація мотиву творчості й образу Поета. У його ліриці поетичне слово від-булося й оприявнилося через ставлення митця до світу, перетворившись на маркер і мірило істинної мови. У художньому вираженні мотиву творчості прочитуються філософські концепції М. Гайдеггера про роль Поета в «убогий час», «епоху відходу Бога», роль сфери «Відкритого», що є засадничою в утвердженні свободи творчості. Якщо «прокляті поети» утілюють буденну, побутову мову (das Gerede), яка $є$ поверховою, то «справжній» Поет є носієм мови істинної, де-автоматизованої (die Sage). Традиційна для української літератури XX століття міфологема «проклятих поетів», попри свою гостроконфліктність, набуває діалектичного вирішення: стилет i стилос - це два рівновеликих крила лірики I. Римарука - естета і водночас поборника громадянського призначення поезії. Продовжуючи традиції «празької школи», поет утверджує високу місію образу Митця, пов'язану з історичним буттям нації. Проаналізований діалог лірики Ігоря Римарука з герменевтичними концепціями М. Гайдеггера відкриває широке поле інтерпретаційних можливостей у тлумаченні філософського дискурсу сучасної модерної української поезії, слугує підгрунтям визначення художньо-філософського феномену мистецтва Слова.

\section{Література}

1. Гайдеггер М. Навіщо поети? Антологія світової літературнокритичної думки ХХ століття [передмови, ред. М.Зубрицької]. Львів : Літопис, 2002. С. 227-249. 
2. Гайдеггер М. Гельдерлін і сутність поезії. Антологія світової літературно-критичної думки ХХ століття [передмови, ред. М. Зубрицької]. Львів : Літопис, 2002. С. 250-261.

3. Ігор Римарук : «Кожна перемога в поезї - піррова». URL: https://day.kyiv.ua/.

4. Комаренець I. Художньо-стильова еволюція I. Римарука // Наукові записки. 2013. Том 134. C. 34-38. URL: http://www.ekmair.ukma.kiev.ua/bitstream/123456789/3215/1/

5. Лебединцева Н. Слово як сакральний дискурс у поетичній рецепції М. Зерова та І. Римарука. Наукові праці. Літературознавство. Вип. 212. Том 224. С. 50-53.

6. Літературознавчий словник-довідник [Р. Гром'як, Ю. Ковалів та ін.]. Київ : ВЦ «Академія», 1997. С. 250.

7. Моренець В. Естетизм. Оксиморон : Літературознавчі статті, дослідження, есеї. Київ : Аграр Медіа Груп, 2010. С. 385-402.

8. Римарук I. Сльоза Богородиці : [поезії]. Київ : Дніпро, 2007. 397 с.

9. Римарук І. Божественний вітер [останні поезіі]. Чернівці : Букрек, 2012. $272 \mathrm{c}$. 